\title{
A Gap Between Theory and Practices: Best Leadership Practices in Multinational Corporations: An Egyptian Case Study
}

Asmaa M.S. Ibrahim

\begin{abstract}
Purpose - This research aims to describe leadership practices that fit into Egypt national culture, in Multinational Companies (MNCs) work environment. Taking two of the top companies in leadership field as an example, this research helps in presenting guidelines for the best leadership practices for MNCs, operating in Egypt.Design/methodology/approach - This research employed qualitative case study, using semi-structured interviews. Two-case studies were conducted to reach more comprehensive findings. Findings -Leadership practices associated with Egypt's national culture are macro managing employees; involving employees in decision making; providing clear vision and objectives; maintaining context which includes providing clear rules and guidelines, coaching employees, maintaining a follow up system on employees performance and maintaining a clear rewarding and penalizing system; and focusing on humane aspects which includes managing conflicts, keeping employees in harmony and considering individuals' differences. Implications- This research highlights a gap between theory and practice. Some of the presented leadership practices presented in this research contradict with the literature's classification for Egypt's' national. This indicates that further research work should be conducted to generalize findings.Originality/value - The research emphasizes that there is a shift in people's perception towards best leadership styles and practices. The cultural aspects identified in this research challenges the classification of Egypt as high power distance and masculine society. Further, findings present new prospective for some of the leadership practices. The paper also proposes that short-term orientation is also a cultural aspect associated with workplace.
\end{abstract}

Keywords: National culture, Humane-orientation, Short-term orientation, Leadership practices, Individualized consideration, Employees' performance, Case study, Interviews analysis techniques

DOI: $10.7176 / \mathrm{DCS} / 9-3-07$

Publication date:March $31^{\text {st }} 2019$

\section{Introduction}

Some multinational companies (MNCs) choose to develop their own cross-culture leadership model. Managers and subordinates, who work in some of those companies, believe that such cross-culture leadership model fits into employees' cultural values and concerns. However, they never identified how such cross-culture leadership models are related to different cultures (Corporate executive board, 2000). Taking 3M Company and General Electric (GE) as examples of leading companies, in the leadership field, this research aims to identify leadership practices that fit into Egypt national cultural aspects and to present a guideline for other MNCs, operating in Egypt. This will be through identifying the leadership practices that fit into Egyptian employees' cultural concerns and presenting the theoretical and practical implications for the identified leadership practices.

Cross-culture leadership is a critical success factor for large multinational corporations (Javidan \& et al., 2006). In this paper cross-cultural leadership will be defined as the interaction between mangers and subordinates from different cultural backgrounds (Suutari \& Tahvanainen,2002), which is affected by the complex pattern of beliefs, expectations, ideas, values, attitudes and behaviors (Debono \& et al., 2008, p. 206) of both leaders and followers. Nevertheless, relatively little research has been carried out on cross-cultural leadership characteristics, competencies, and strategies, based on specific cultural context (Morrison, 2000; Javidan \& et al., 2006; Ibrahim, 2014.a; Ibrahim, 2014.b; Ibrahim, 2014.c). Among the researchers conducted were Suutari (1996.a) and Van Oudenhoven (2001) whom presented different frameworks addressing leadership in cross cultural settings, in general.

Suutari (1996.a) used Hofstede's suggestions to identify eight aspects of leadership that are significantly related to national culture. These leadership aspects are decision participation, autonomy-delegation, rewarding, production emphasis, role clarification, conflict management, individualized consideration and providing vision (Suutari, 1996.a). According to this researcher, decision participation is the extent to which a leader consults with subordinates or allows them to participate in making decisions. Autonomy-delegation is the extent to which a leader allows subordinates to decide on how to do their job, fulfill tasks and objectives. Rewarding aspect is the extent to which a leader considers rewarding subordinates for doing their job well. Production emphasis is the extent to which a leader emphasizes and tries to improve productivity and efficiency. Role clarification is the extent to which a leader clarifies the rules and provides detailed descriptions of the required task. Conflict management is the extent to which a leader helps subordinates to resolve internal conflicts with their colleagues. Individualized consideration is the extent to which a leader is supportive and deals in an open way with subordinates. Providing vision is the extent to which a leader provides followers with a vision of where the 
organization is heading in the future (Suutari, 1996.a).

Further, based on Hofstede's cultural model, Van Oudenhoven (2001) presented other leadership practices associated with national culture which are; the decision making, the level of rules and regulations formalization, the level of career orientation/relationship orientation, and the level of separation between work and personal life. The decision-making process is associated with the degree of power distance, the rules and regulations level of formalization associated with the degree of uncertainty avoidance, the level of career orientation versus relationship orientation associated with the degree of masculinity, and the level of separation between work and personal life associated with the degree of individualism. Suutari (1996.a), and Van Oudenhoven (2001) work guided this research interview questions and data analysis and coding (see interview questions, in the Appendix).

\section{Research Methodology}

This section explains the research process, sampling procedure and sample size, data gathering process, data processing and coding and data analysis methods.

\subsection{Research process}

To demonstrate the leadership practices that fit into Egypt national cultural aspects based on employees' perception, two case studies were conducted, on two of the top companies in leadership field, with replication logic. Case study was employed to obtain an in-depth insight, in real-life context (Yin, 2003, p. 9). The case study method was chosen because: first, the research mainly focuses on exploring a process; second, the study focus is a contemporary event rather than historical events; third, the study does not require control over behavioral events (Yin, 2003, p. 1). Based on the study nature, the number of cases that are enough to be studied is "quite irrelevant as sampling logic should not be used" (Yin, 2003, p.51). This decision mainly depended on the number of case replications needed to reach robust findings (McCracken, 1988, p.17). Thus, the main objective of employing the replication logic was to conduct further case studies until the case studies findings confirm together, which indicates that the study internal validity is high (Yin, 2003, p.47). In the current study, two case studies were conducted as each case study served a specific purpose. First, case study I was conducted with the objective of presenting findings that can be used for further case studies. Second, case study II was conducted with the objective of testing the validity of case study I findings. Third, a cross-cases comparison was conducted to present more comprehensive findings and description (See Table 3. Case study I and case study II cross-cases findings, in the appendix).

\subsection{Sampling procedure and sample Size}

This study intended to consider all the organizational hierarchy, instead of focusing only on the perceptions of middle managers (Suutari \& Tahvanainen, 2002; Jepson, 2009). Thus, "purposive" sampling was employed to make sure that participants are from different categories (Creswell, 1994, p.148; Devers \& Frankel, 2000; Silverman, 2000, p.104). The study sample included Egyptian managers, and their Egyptian subordinates in different business units/functions, and through all managerial and non-managerial positions. Case study I included 18 interviews which count for $60 \%$ of employees. The study conducted interviews with 7 top managers, 7 middle managers, and 4 subordinates. Case study II included 35 interviews which count to $40 \%$ of employees. The study conducted interviews with 8 top managers, 10 middle managers, and 17 subordinates. It is important to mention that only employees who were interested in the study and willing to participate were selected.

\subsection{Data gathering}

This study conducted semi-structured interviews as the major source of data gathering. The semi-structured interviews helped in refining and expanding the structured questions upon the interviewees' responses (Burgess \& Dyer, 2009). This helped in considering the discrepant evidence in order to maintain data verification and dependability (Creswell, 1994, p.34). Having a structure for interviews helped the researcher in directing participants, since that in Egypt people tend to prefer more structured settings (Leat \& El-Kot, 2007; Ibrahim, 2014.b).

\subsection{Data processing and coding}

The interview dialog was manually recorded in a data recording protocol that was designed based on Creswell (1994, p.152) guidelines (see sample of data recording protocol, in the Appendix). Verbatim transcripts of the interview's testimony were created by the researcher. This helped the researcher to pay attention to ask more clearly audible questions, as well as ensuring to receive clear answers during the interview (Kvale, 1996, p.169). Transcripts were amended based on interviewees' feedback as part of the members check process. Also, the researcher reached out respondents for feedback about the credibility of data collected findings and conclusion to establish validity and ensure verification (Creswell, 1998, p.213; Maxwell, 2005, p.110). The data were initially coded based on the interview questions. Later, categories were refined, and further categories were developed 
based on interviewees' words and phrases that repeated frequently and reflected an important idea for the study research questions (Rubin \& Rubin, 1995, p. 230). The researcher focused on participants' original words which they used to answer the research questions. The researcher compared the words across all the different concepts tackled by all participants. When the whole process of coding was completed, the whole ideas, concepts and categories were reorganized, re-categorized, and refined (Rubin \& Rubin, 1995, p. 228). This stage was guided by the interviews analysis techniques. This process was tackled using two main approaches; first examining each interview to condense its meanings and create categories (condensation of meaning and categorization of meaning); second grouping all interviewees' answers to reach more comprehensive findings (structuring of meaning through narratives) (Kvale, 1996, p.187).

Condensation of meaning helped in reducing the large interview texts into succinct statements, the researcher compressed participants' descriptions into few words (Kvale, 1996, p.192). First, each interview was read as a whole, to get a comprehensive sense of it and to determine the "meaning unites" expressed by the participants. Second, the researcher stated the central theme of the units mentioned in a simplified way. (Kvale, 1996, p.194). Fourth, the theme of the meaning unites were interrogated based on the main purpose of the study. Through the condensation process the researcher was able to highlight the main topics which the participants highlighted. This helped in realizing the overall theme and concepts of data collected and guided in the way the researcher presented the case study findings (see Table 1. summary of leadership practices that fit into national culture aspects).

Categorization of meaning guided the researcher in presenting the different categorize that were highlighted based on interviewees' own words, regardless of the number of participants who confirm or disagree with them (Kvale, 1996, p.192, p.198). In order to develop more sound categories, the researcher intensively read each interview's transcript to identify the main themes and concepts. The main theme developed was the leadership practices recommend based on the cultural aspects that impact employees' performance at work place (see figuer1figure 5). The categorization process served many purposes. First the categorization gave a structure for the extensive interviews. Second, the categorization also made it possible to compare this case study finding to other investigations done in other cases; i.e. case study II (Kvale, 1996, p.199).

Structuring of meaning through narratives helped the researcher in putting everything together across multiple participants. This stage focused on the "condensation and reconstruction of the many tales told by different subjects" to develop a more comprehensive story, rather than depending on scattered stories highlighted by each single interviewee (Kvale, 1996, p.199). Structuring meaning through condensing all participants narratives, based on categorizes and unties of meaning, help in presenting richer, condensed and more coherent story. Each category or unit of meaning was mainly supported with stories told by different participants (Kvale, 1996, p.199). This was directly presented in the research findings (see findings and discussion section).

\subsection{Data analysis Method}

Since that the study conducted two-case studies, cross-case synthesis technique was employed (Yin, 2009, p.156). The researcher tackled each case study individually, and then aggregated the findings (Yin, 2009, p.156). This helped in identifying and clarifying the unique patterns of each case study and reaching a comprehended generalizable pattern across cases (Huberman \& Miles, 2002, p.18).

The cross-cases findings were presented through constructing word tables that display the data from each case study to identify the similarities and differences between both cases (See Table 3. Case study I's and case study II's cross-cases findings, in the appendix). Then cross-cases discussion was conducted based on the entire collection of word tables constructed, to present a comprehensive cross-cases model (Yin, 2003, p.135). This discussion depended on argumentative interpretation rather than statistics (Yin, 2003, p.137).

\section{Findings and discussion}

This section presents the research findings which reveals the leadership practices that fit into Egyptian employees' cultural concerns. This was mainly presented based on conceptually ordered meta-matrices that include case I and case II cross-cases findings (See the conceptually ordered meta-matrices, Table 3. Case study I's and case study II's cross-cases findings, in the Appendix). The, meta-matrices were developed as a result of using the interview analysis techniques. The interview analysis techniques helped the researcher develop the main categories provided in this section. Those categories where developed from participant's answers to the interview questions. Based on research findings, the leadership practices associated with Egypt national culture are macro managing employees; involving employees in decision making; providing clear vision and objectives; maintaining context; and focusing on humane aspects. Also, based on findings, the section presents extensive guidelines for leadership styles and practices that fits into Egypt national culture, based on participants' experience. Moreover, in this section the researcher compares the leadership practices associated with Egypt national culture based on research findings to leadership practices associated with national culture based on literature, which were mainly identified by Suutari (1996.a), and Van Oudenhoven (2001). (See Table 1. for Summary of leadership practices associated with Egypt national culture) 


\subsection{Macro management}

Based on the current research findings, leaders focus on macro managing employees. This was highlighted in both case study I and case study II. This confirms with leadership practices associated with national culture as identified by Suutari (1996.a), mainly autonomy-delegation. Autonomy-delegation focused on the extent to which leaders allows subordinates to decide on how to do their job, fulfill tasks and objectives (Suutari, 1996.a).

The leadership practice identified by participants fits into the democratic leadership styles. democratic leadership styles focus on guiding employees rather than giving them directive orders, at work to get commitment from employees (Rivenbark, 2006). Based on participants this requires leaders to focus on clarifying responsibilities, providing clear guidelines, and giving space in implementation.

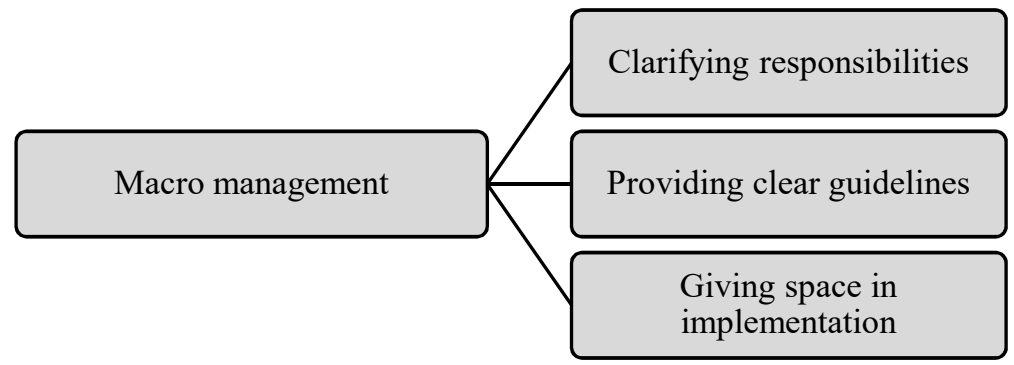

Figure 2. Macro management fits into employees' tendency to value freedom

Source(s): researcher.

As highlighted by participants and supported in literature, managing employees includes giving employees space to create. It also includes empowering employees. Empowering helps in developing mutual trust between leaders and subordinates. As highlighted by one of the participants, "Empowering improves leaders-subordinates relationship, which in turn affects employees' performance". On the other hand, as highlighted by another participant "demanding immediate compliance and asking subordinates to do what they are told to do, decrease subordinates' ability to act on their own initiatives or according to their own decisions". This, consequently, decrease employees' sense of ownership and feel little accountability for their performance (Goleman, 2000).

Macro management was identified by participants as it fits into the employees' cultural aspect to values freedom. As highlighted by one of the participants "Employees' tendency to value freedom implies that they like to have space, room for creativity, and flexibility; they like to do things in their own way; and they tend to reject tight control". This may contradict with literature's classification for Egypt as a high-power distance culture where employees tend to depend totally on their leaders (Sidani, 2006). However, Egyptian's attitude towards power distance started to change lately (Nafie, 2012; Ibrahim, 2014.b).

\subsection{Participation in decision making}

Based on the current research findings, leaders involve employees in decision making. Leaders, also, take subordinates' suggestions and feedback into consideration. This was highlighted in both case study I and case study II. This confirms with leadership practices associated with national culture as identified by Suutari (1996.a) and Van Oudenhoven (2001), mainly decision participation and the decision-making process respectively. Both researchers focused on the extent to which leaders consults with subordinates or allow them to participate in making decisions.

The leadership practices identified by participants fit into the participative leadership style. Participative leadership style focuses on consulting subordinates in decisions, especially the decisions that will affect them (Dickson \& et al., 2003). Based on participants, this process must be well regulated as in some cases decisions have to be centralized. As stated by one of the participants "sometimes leaders have to make some decisions without referring to subordinates. In case of centralizing decisions, leaders should help employees understand the rationale behind this decision". This practice helps in decreasing ambiguity and increasing clarity and transparency.

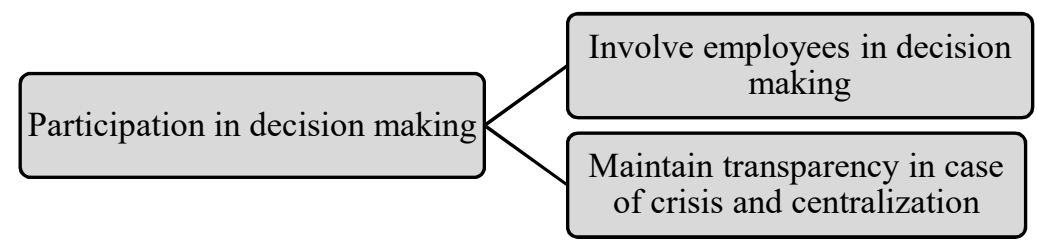

Figure 3. participation in decision making fits into employees' tendency to value discussion Source(s): researcher.

As highlighted by one of the participants "involving employees in decision making increases their level of trust towards leaders, this in turn decreases their resistance towards following ambiguous decisions". Also, as highlighted by one of the participants, "involving employees in decision making increases the mutual 
understanding between employees and managers". Moreover, as highlighted by another participant "involving employees in decision making help in reaching shared purpose". Consequently, this increases employees' loyalty, commitment, and sense of ownership (Ibrahim, 2014.b). This in turns, helps in increasing employees' sense of security as they feel that leaders consider their concerns in the decision making.

This leadership practice was identified by participants as it fits into employees' tendency to value discussion and participation in decision making and reject directive orders. This may contradict with literature's classification for Egypt as a high-power distance culture where people tend to accept centralized power structure (Hofstede, 1994.a; Hofstede, 1994.a; Flynn \& Saladin, 2006). However, this new trend may be justified since that people beliefs, expectations, and attitudes can change over time (Debono \& et al., 2008, p. 206; Nafie, 2012; Ibrahim, 2014.b).

\subsection{Providing clear vision and objectives}

Based on the current research findings, leaders help employees see the big picture, realize the purpose of objectives, and understand their role to fulfill them. This was highlighted both in case study I and case study II. This confirms with leadership practices associated with national culture as identified by Suutari (1996.a), mainly providing vision. Suutari (1996.a) defined it as on the extent to which a leader provides a vision of where the organization is heading in the future.

The leadership practices identified by participants fit into the visioning leadership style. Visioning leadership style focuses on creating and communicating clear vision to help employees have clear picture for the future (Goleman, 2000; Rivenbark, 2006.114). Based on participants, this practice needs leaders who have clear picture for future; can develop long-term focus and link both long-term to short-term; can help employees in realizing purpose of objectives; and can help subordinates realize their role to fulfill the objectives.

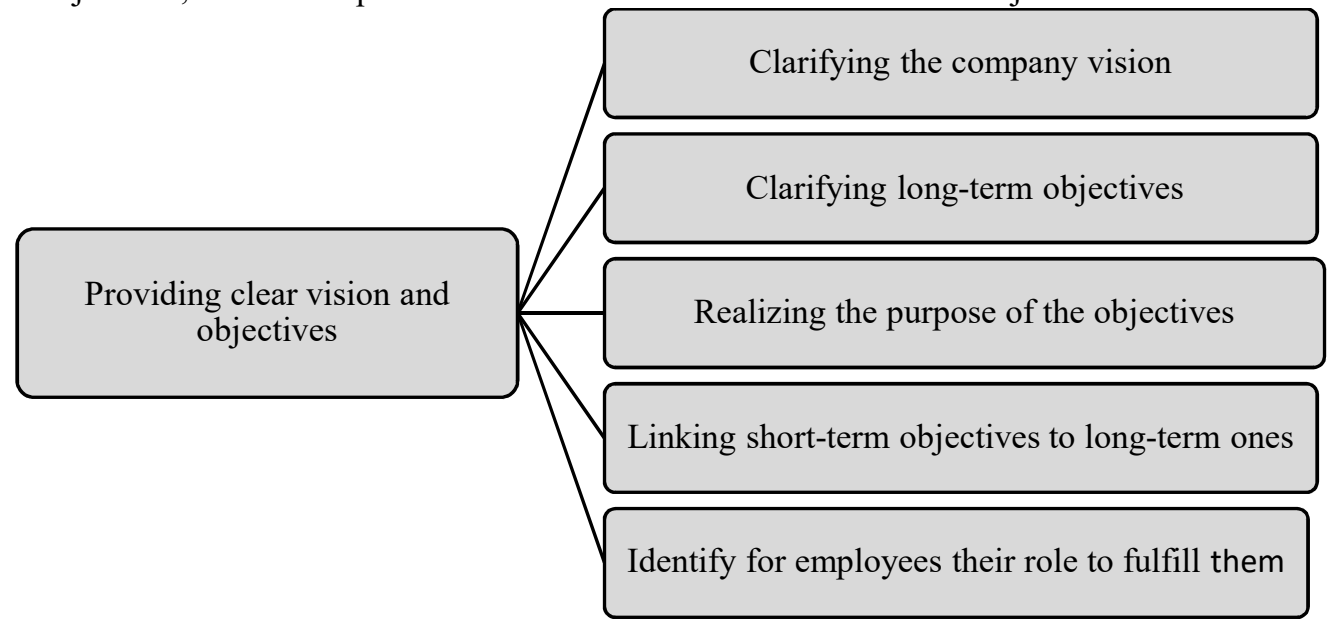

Figure 4. providing clear vision and objectives fits into employees' tendency to focus on short-term aspects Source(s): researcher.

As highlighted by one of the participants "updating employees with the company situation and business trends and helping employees realize the long-term objectives to develop a sound plan and short-term actions helps subordinates know where the company stands". Further, another participant highlighted that "being aware of the company situation, motivates employees as they get to know how they can help the company develop more". Moreover, as highlighted by another participant "updating employees with the company current situation and future and clarifying long term objectives, increases transparency". This increases employees' sense of security, as it decreases ambiguity which affect employees' motive and engagement at work.

This leadership practice was identified by participants as it helps in regulating employees' tendency to focus on short-term aspects. In Egypt some employees may tend to focus on rapid response, rather than future implications. This fits into literature classification for past oriented-cultures (Trompenaars \& Hampden-Turner, 1998, p.125).

\subsection{Maintaining clear context}

Based on the current research findings, leaders focus on maintaining clear context this includes communicating clear rules and guidelines and clarifying employees' benefits and rewards. These leadership practices were highlighted in case I and case II. This confirms with leadership practices associated with national culture as identified by Suutari (1996.a), mainly role clarification, production emphasis, and rewarding. Role clarification focused on the extent to which a leader clarifies the rules and provides detailed descriptions of the required task (Suutari, 1996.a). Production emphasis focused on the extent to which a leader emphasizes and tries to improve productivity and efficiency (Suutari, 1996.a). Rewarding aspect is the extent to which a leader considers rewarding 
subordinates for doing their job well (Suutari, 1996.a). Findings also confirms with Van Oudenhoven (2001)'s leadership aspect that focuses the level of formalization rules and regulations.

The leadership practices identified by participants fit into the transactional-leadership style. Transactionalleadership style focuses on clarifying role and task requirements, provide appropriate rewards, and coordinating work (Suutari, 1996.a; Ibrahim, 2014.b). One of the participants said, "to successfully implement this (helping subordinates reach objectives under clear context), leaders should be able to provide clear instructions through considering all deliverables and constraints and developing a time frame to fulfill objectives". Another participant stated that leaders should be able to coach employees "leaders should help subordinates develop a yearly plan to meet objectives, identify subordinate's weakness and strengths, and provide them with facilities, resources and guidance needed". In addition, another participant stressed on the idea of having systematical follow up process; "follow up on employees' progress to make sure that they are on the right track; provide help if needed; and highlight rewards and penalties through creating the culture of mistakes are lessons learnt". Further, another participant emphasized that "leaders should clarify that violating well communicated rules and policies is intolerable and subject to penalties". On the other hand, this participant emphasized that "leaders should also nurture the culture of rewarding and acknowledging employees' efforts and added value".

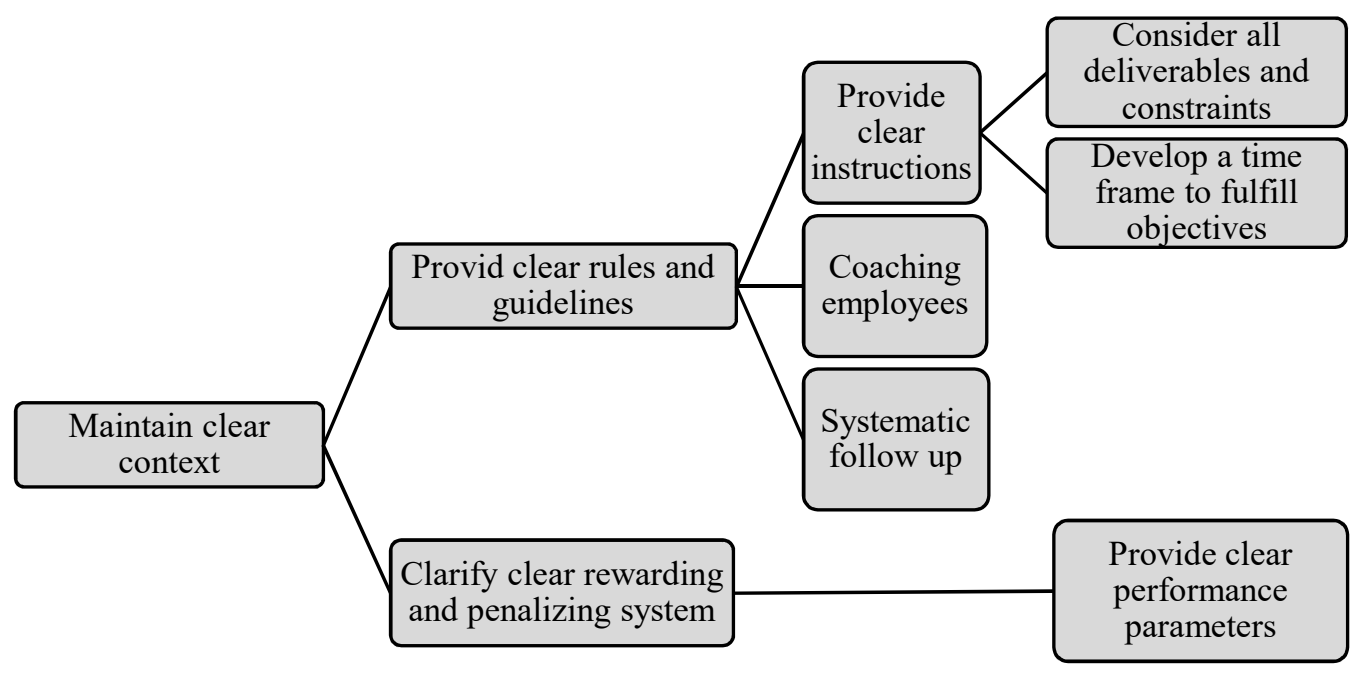

Figure 5. maintaining clear contexts to fit into employees' tendency to value working under clear context and uncertainty Source(s): researcher.

As highlighted by participants and supported in literature, providing detailed descriptions of the required tasks decreases employees' confusion, and increases employees' productivity (Debono \& et al., 2008, p.244). Working in an organization that provides clear rules and regulations helps employees feel comfortable and accept taking extra tasks (Rivenbark, 2006). Further, the company approach towards mistakes, along with its follow up system increase employees' sense of security, as it helps them focus on dealing with problems and decreasing mistakes. As one of the participates stated "the follow up system that focus on helping employees fulfill requirements and handle problems increases employees' sense of support, decreases their fear from committing mistakes, and consequently increases their motive and commitment to work".

The leadership practices identified by participants fits into employees' tendency to value clear context and avoid uncertainty. This confirms with literature that classified Egypt among the high uncertainty avoidance culture (HassabElnaby \& Mosebach, 2005; Leat \& El-Kot, 2007; Debono \& et al., 2008, p. 203; Ibrahim, 2014.b). In such cultures, employees tend to value working under a clear and structured work environment (Suutari, 1996.a; Leat \& El-Kot, 2007; Debono \& et al., 2008, p. 203). They tend to avoid unfamiliar situations and tasks in order to avoid uncertainty (Ibrahim, 2014.b).

\subsection{Focus on humane aspects}

Based on the current research findings, leaders focus on managing conflicts, handling socialization and relationship, and considering individuals' differences. This was highlighted in both case study I and case study II. This confirms with leadership practices associated with national culture as identified by Suutari (1996.a), mainly conflict management, and individualized consideration. Conflict management is the extent to which a leader helps subordinates to resolve internal conflicts with their colleagues (Suutari, 1996.a). Individualized consideration is the extent to which a leader is supportive and deals in an open way with subordinates (Suutari, 1996.a). It also fits 
with the level of career orientation versus relationship orientation, and the level of separation between work and personal life, that were highlighted by Van Oudenhoven (2001 page 106).

The leadership practices identified by participants fit into the humane-oriented leadership practices. Humaneoriented leadership focuses on developing good relationships with subordinates; focusing on humane consideration; and focusing on supporting and improving interpersonal relations at work (Grotenhuis, 2001; Jones \& George2003, p.453; Harris \& Carr, 2008; Ibrahim, 2014.b). Based on of the participants "this requires leaders who can clarify accountability and help subordinates deal with conflicts form an objective rather than personal prospective. It also needs leaders who are able to nurture good team spirit and healthy relationship between employees, while helping employees mange conflict of interest". Moreover, as highlighted by another participant "it needs leaders who consider individuals' nature, personality, personal circumstance, and special religions and social norms".

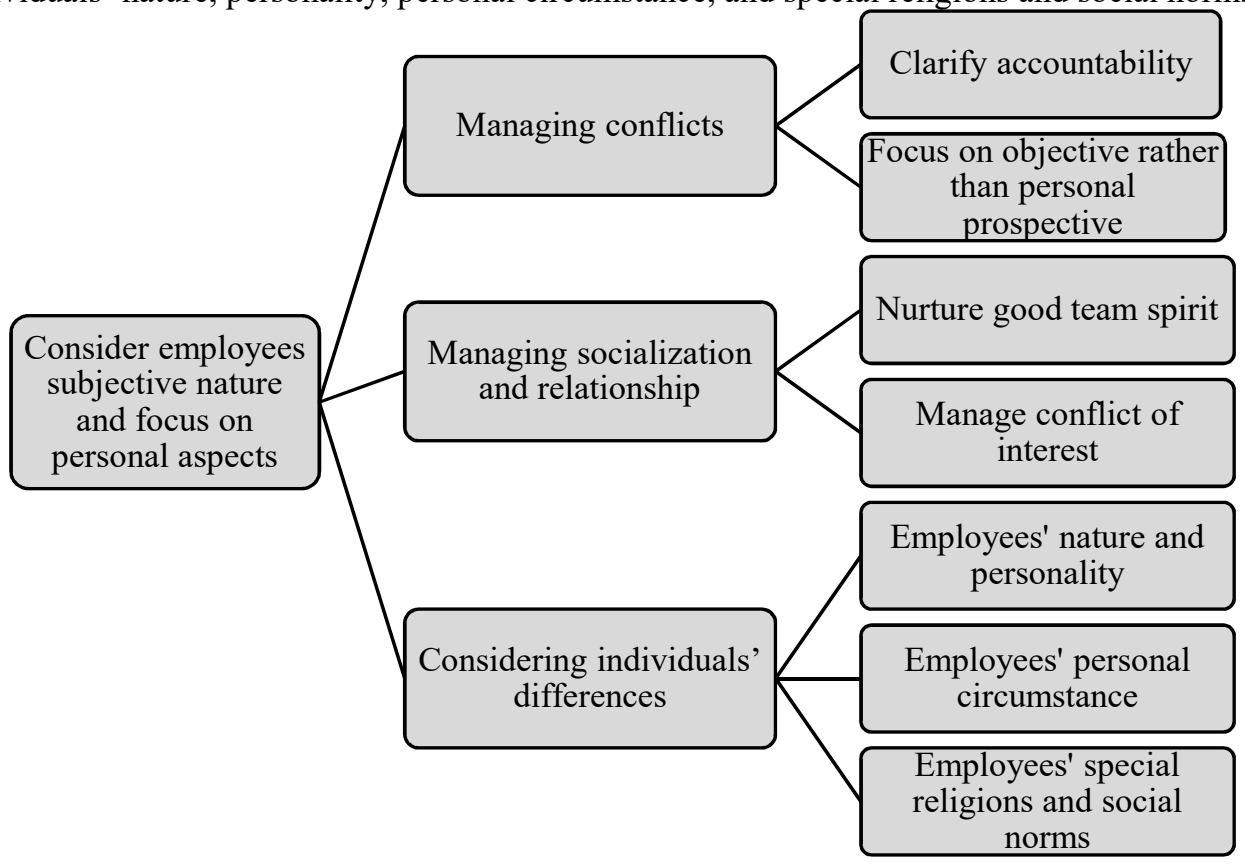

Figure 6. focus on humane-oriented practices to fit into employees' tendency to be subjective and focus on humane aspects Source(s): researcher.

As highlighted by one of the participants, and supported in literature, "leaders' supportive manner in managing conflicts helps subordinates in retaining their sense of steadiness, decreasing subjective judgment, maintaining respect towards others, and accepting leaders' judgment to get over the conflict". Another participant supported this idea saying that "leaders' role in managing conflict through clarifying accountability decreases confusion, which in turns decreases the potential for conflicts". This help in maintaining employees' relationship which intern affects their motive and performance (Goleman, 2000). Further, socialization and developing healthy relationships help in improving employees' performance (Trompenaars \& Hampden-Turner, 1998, p.83; Goleman, 2000). Moreover, giving individualized consideration to subordinates increases employees' sense of security, motivation, satisfaction, and consequently performance (Goleman, 2000).

These practices were identified by participants as they fit into their employees' tendency to be subjective and focus on humane aspects. This confirms with literature classification, as people in Egypt value socialization and nurturing relationship (Leat \& El-Kot, 2007; Mostafa \& El-Masry, 2008; Ibrahim, 2014.b; Ibrahim, 2014.c). They tend to avoid confrontation and conflict as they create uncertainty as this may negatively affect their relationship with others. Also, they appreciate taking care of others and doing extra things for their sake (Javidan \& et al., 2006; Ibrahim, 2014.b).

3.6 Summary of leadership practices associated with Egypt national culture

The table presents the identified leadership practices classified based on employees' cultural concerns and supported with guidelines for implementation. 
Table 2. Summary of leadership practices associated with Egypt national culture

\begin{tabular}{|c|c|c|}
\hline $\begin{array}{l}\text { Employees' } \\
\text { concerns }\end{array}$ & Leader's practices & Description \\
\hline $\begin{array}{l}\text { Employees' } \\
\text { tendency to value } \\
\text { freedom }\end{array}$ & $\begin{array}{l}\text { Macro managing } \\
\text { employees }\end{array}$ & $\begin{array}{l}\text { - } \quad \text { Clarify objectives, responsibilities, rules, and guidelines } \\
\text { - } \quad \text { Give subordinates the space to fulfil objective in their own way }\end{array}$ \\
\hline $\begin{array}{l}\text { Employees' } \\
\text { tendency to value } \\
\text { discussion }\end{array}$ & $\begin{array}{ll}\text { Participation in } \\
\text { decision making }\end{array}$ & $\begin{array}{l}\text { - Involve employees in decision making, and take their feedback } \\
\text { into consideration } \\
\text { - } \quad \text { Maintain transparency in case of crisis and centralization }\end{array}$ \\
\hline $\begin{array}{l}\text { Employees' } \\
\text { tendency to focus } \\
\text { on short-term } \\
\text { aspects }\end{array}$ & $\begin{array}{lr}\text { Providing } & \text { clear } \\
\text { vision } & \text { and } \\
\text { objectives } & \end{array}$ & $\begin{array}{l}\text { - } \text { Clarify the company vision } \\
\text { - } \quad \text { Clarify long-term objectives } \\
\text { - } \quad \text { Explain the purpose of the objectives } \\
\text { - } \quad \text { Link short-term objectives to long-term ones } \\
\text { - } \quad \text { Identify for employees their role to fulfil them } \\
\end{array}$ \\
\hline \multirow{3}{*}{$\begin{array}{l}\text { Employees' } \\
\text { tendency to value } \\
\text { clear context }\end{array}$} & $\begin{array}{l}\text { Provide clear rules } \\
\text { and guidelines }\end{array}$ & $\begin{array}{l}\text { - } \quad \text { Consider all deliverables and constraints } \\
\text { - } \quad \text { Develop a time frame to fulfil objectives }\end{array}$ \\
\hline & $\begin{array}{l}\text { Coaching and } \\
\text { maintaining a } \\
\text { follow up system on } \\
\text { employees' } \\
\text { performance }\end{array}$ & $\begin{array}{l}\text { - Help employees develop a yearly plan to meet objectives } \\
\text { - Identify subordinate's weakness and strengths } \\
\text { - } \quad \text { Provide subordinates with facilities, resources and guidance } \\
\text { needed. } \\
\text { - } \quad \text { Follow up on their progress to make sure that employees are } \\
\text { on the right track } \\
\text { - } \quad \text { Provide them with more guidance when needed. }\end{array}$ \\
\hline & $\begin{array}{l}\text { Maintaining a clear } \\
\text { rewarding and } \\
\text { penalizing system }\end{array}$ & $\begin{array}{l}\text { - Create the culture of mistakes are lessons learnt } \\
\text { - Clarify that violating well communicated rules and policies is } \\
\text { intolerable and subject to penalties } \\
\text { - Nurturer the culture of rewarding and acknowledging } \\
\text { employees' efforts and added value. }\end{array}$ \\
\hline \multirow{3}{*}{$\begin{array}{l}\text { Employees' } \\
\text { tendency to be } \\
\text { subjective and } \\
\text { focus on humane } \\
\text { aspects }\end{array}$} & Managing conflicts & $\begin{array}{l}\text { - } \quad \text { Clarify accountability } \\
\text { - Help subordinates in dealing with conflicts based on an } \\
\text { objective rather than a personal prospective. }\end{array}$ \\
\hline & $\begin{array}{l}\text { Keep employees in } \\
\text { harmony }\end{array}$ & $\begin{array}{l}\text { - Nurture good team spirit and healthy relationship between } \\
\text { employees } \\
\text { - } \quad \text { Help employees mange conflict of interest }\end{array}$ \\
\hline & $\begin{array}{l}\text { Considering } \\
\text { individuals' } \\
\text { differences }\end{array}$ & $\begin{array}{l}\text { - } \quad \text { Consider individuals' nature, personality, } \\
\text { - } \quad \text { Personal circumstance } \\
\text { - } \quad \text { Special religions and social norms }\end{array}$ \\
\hline
\end{tabular}

\section{Research implications}

4.1 Practical implications: guidelines for the best leadership practices for MNCs, operating in Egypt

During the interviews, both leaders and subordinates highlighted some guidelines to implement the leadership practices that fits into Egypt national culture, based on participants' work experience in multinational companies. For example, macro managing employees requires leaders to clarify subordinates' responsibilities and provide guidelines while, at the same time, allowing subordinates to decide on how to reach objectives. This in turn needs high responsibility from subordinates. Moreover, allowing subordinates to participate in decision making is essential to gain their commitment. Yet, as some decisions must be centralized leaders should focus on decreasing ambiguity and increasing transparency and gain subordinates' commitment. In this case leaders should help subordinates understand the rationale behind those decisions and help subordinates in aligning their work objectives to successfully implement the centralized decisions. Further, leaders are expected to help in maintaining transparency in workplace. Leaders should maintain clear context. This requires a leader who can provide guidelines, instructions and resources needed to meet objectives. This leader should also help subordinates stay on track to attain goals. This also requires a clear policy for rewards and penalties. Furthermore, leaders are expected to be humane-oriented. Leaders are expected to nurture a good team spirit and help subordinates manage conflicts between team members. Leaders also expected to consider subordinates' individual nature, personality, and personal circumstances. 


\subsection{Theoretical implications}

The research findings confirm with some of the leadership practices associated with national culture as suggested by Suutari (1996.a) and Van Oudenhoven (2001), while contradicting with others. More importantly, the study findings present new prospective for some of leadership practices, based on participants' cultural concerns.

\subsubsection{Power distance}

Research findings confirm with Van Oudenhoven (2001) that participation in decision making is associated with the degree of power distance. The study findings also agree with Suutari (1996.a) that macro management and autonomy-delegation is also associated with the degree of power distance, or as the current research define it as people tendency towards freedom and discussion.

\subsubsection{Uncertainty avoidance}

Further, the study confirms with Van Oudenhoven (2001) findings that the level of formalizing rules and regulations is associated with uncertainty avoidance. Additionally, the study findings agree with Suutari (1996.a) that role clarification and providing vision is associated with uncertainty avoidance. However, the study did not completely confirm with Suutari, (1996.a) that conflict management is associated with uncertainty avoidance. On one side the study findings highlighted that conflict management can create uncertainty which may negatively affect the relationship between employees. Thus, the researcher believes that conflict management fits more into the nature of interaction and reaction between employees. Thus, in the current study conflict management is associated with what participants call humane-orientation.

Furthermore, the current research proposes that, coaching employees, maintaining a follow up system, and maintaining a clear rewarding and penalizing system are also associated with uncertainty avoidance, or as the research define it as people tendency towards having clear context.

4.2.3 Femininity/masculinity and Collectivism/individualism

Moreover, the study confirms with Van Oudenhoven (2001) findings that the level of career orientation/relationship orientation is associated with femininity/masculinity, and the level of separation between work and personal life is associated with collectivism/individualism. Based on Suutari (1996.a) individualized consideration indicates the degree of individualism, while production emphasis indicates masculinity. However, in the current study, individualized consideration, which indicates that leaders focus on supporting subordinates, reflects more collectivistic and femininity cultural values rather than individualistic cultural values. Thus, in the current research individualized consideration is associated with what the participates called humane-orientation. More importantly, participants' statements did not reflect on the degree of production emphasis.

\subsubsection{Humane-orientation}

The current research proposes that the level of managing conflicts, keeping employees in harmony and considering individuals' differences are associated with what the study call people tendency to be subjective, and focus on humane aspects (humane-orientation).

4.2.5 Short-term orientation

Moreover, the study proposes further, that the level of providing employees with clear vision and objectives are associated with employees' short-term orientation. Leadership practices based on employees' short-term orientation is not thoroughly presented in literature.

4.2.6 Summary

The following table presents a summary for the leadership practices associated with national culture based on the current research findings and leadership practices associated with national culture based on literature. 
Table 2: Comparing the Current Study Findings to Literature

\begin{tabular}{|c|c|c|}
\hline Findings based on & $\begin{array}{lr}\text { Cultural } & \text { aspects } \\
\text { associated } & \text { with } \\
\text { workplace } & \end{array}$ & Leadership practices associated with national culture \\
\hline \multirow{4}{*}{$\begin{array}{l}\text { Van Oudenhoven } \\
(2001)\end{array}$} & Power distance & Decision making process \\
\hline & Uncertainty avoidance & The level of formalizing rules and regulations \\
\hline & Femininity /masculinity & $\begin{array}{l}\text { The level of career orientation versus relationship- } \\
\text { orientation }\end{array}$ \\
\hline & $\begin{array}{l}\text { Individualism/ } \\
\text { collectivism }\end{array}$ & The level of separation between work and personal life \\
\hline \multirow[t]{4}{*}{ Suutari (1996.a) } & Power distance & $\begin{array}{l}\text { Participation in Decision } \\
\text { Autonomy-delegation }\end{array}$ \\
\hline & Uncertainty avoidance & $\begin{array}{l}\text { The role clarification } \\
\text { Conflict management } \\
\text { Providing vision }\end{array}$ \\
\hline & Masculinity & Degree of individualized consideration \\
\hline & Individualism & Rewarding and production emphasis \\
\hline \multirow[t]{4}{*}{ Current study } & Power distance & $\begin{array}{l}\text { Tendency towards freedom and discussion: } \\
\text { Degree of macro managing (work autonomy) } \\
\text { Involving employees in decision making }\end{array}$ \\
\hline & Uncertainty avoidance & $\begin{array}{l}\text { Tendency towards having clear context: } \\
\text { Providing vision } \\
\text { Role clarification } \\
\text { Coaching employees and maintaining a follow up } \\
\text { system on employees' performance } \\
\text { Maintaining a clear rewarding and penalizing system }\end{array}$ \\
\hline & Humane-orientation & $\begin{array}{l}\text { Tendency to be subjective and focus on human } \\
\text { aspects: } \\
\text { Managing conflicts } \\
\text { Keeping employees in harmony } \\
\text { Considering individuals' differences (individualized } \\
\text { consideration) }\end{array}$ \\
\hline & Past-orientation & $\begin{array}{l}\text { Providing vision } \\
\text { Providing clear rules and guidelines } \\
\text { Coaching employees and maintaining a follow up } \\
\text { system on employees' performance }\end{array}$ \\
\hline
\end{tabular}

\section{Suggestions further research work}

Based on findings the researcher suggests that further studies should be conducted to verify the leadership practices associated with high power distance, short-term orientation, and femininity/masculinity.

\section{Limitations}

Interview studies are criticized as findings are not generalizable. This is mainly because there are too few subjects (Kvale, 1996, p. 102). Also, the research assumes that the individuals participating in the study mirror culture of the society they come from. This is known as the ecological fallacy error (Dickson et al. 2003; Scandura \& Dorfman, 2004). Moreover, different organizational context could yield different results. Thus, applying this research to multinational companies MNC with different origins or in different sectors might show different results.

\section{Conclusion}

The main objective of this study is to discover and describe the leadership practices that fit into Egypt national cultural aspects, mainly applied by top multinational companies in leadership area. This research employed qualitative case study, using semi-structured interview questions. In selecting participants, purposive sampling was employed to make sure that interviewees are from different organizational hierarchy. The semi-structured interview helped in providing a structure while allowing the researcher to expand the structured questions based on participants' answers. Two case studies were conducted, on two of the top companies in leadership field, with replication logic. The first case study was conducted with the objective of presenting findings that can be used for 
further studies. The second case study was conducted with the objective of testing the validity of the first case study findings. The researcher analyzed findings using cross-case synthesis technique. The researcher tackled each case study individually, and then aggregated the findings. The cross-cases comparison helped the researcher in presenting more comprehensive findings and description.

Based on research findings, the leadership practices associated with Egypt national culture are macro managing employees (which includes clarifying responsibilities, providing clear guidelines, and giving space in implementation); involving employees in decision making (which includes involving employees in decision making and maintaining transparency in case of crisis and centralization); providing clear vision and objectives (which includes clarifying the company vision, clarifying long-term objectives, realizing the purpose of the objectives, linking short-term objectives to long-term ones, and identify for employees their role to fulfill them); maintaining context (which includes providing clear rules and guidelines, providing clear instructions, developing a time frame to fulfill objectives, coaching employees, maintaining a follow up system on employees performance, maintaining a clear rewarding and penalizing system, and providing clear performance parameters); and focusing on humane aspects (which includes managing conflicts, clarifying accountability, helping employees focus on objective rather than personal prospective, keeping employees in harmony, managing socialization and relationships between employees, nurturing good team spirit, helping employees manage conflict of interest, considering individuals' differences, considering employees' nature and personality, considering employees' personal circumstance, considering employees' special religions and social norms). The research findings highlight a gap between theory and practice. Some of the presented leadership practices contradict with the literature's classification for Egypt's' national. The cultural aspects identified in this research challenges the classification of Egypt as a high power distance and masculine society. Findings also propose that short-term orientation is a cultural aspect associated with workplace. This indicates that further research work should be conducted to generalize findings.

\section{Appendix}

-The interview questions

- The questions directed to the Egyptian managers and Egyptian subordinates focused on helping them identify:

○ The leadership styles, leaders' activities, leaders' practices, and leaders' attitude towards subordinates, in Egyptian subsidiary

- The successful leadership styles, leaders' activities and leaders' practice, in the Egyptian subsidiary, which the participants believe that they, fit into the Egyptian culture (i.e., beliefs, expectations, ideas, values, attitudes and behavior)

-Data recording protocol

- This protocol was guided based on Creswell (1994, p. 152)

\begin{tabular}{|l|l|}
\hline Case \#.\# & \\
\hline Interview \# & \\
\hline Date & \\
\hline Time & \\
\hline Company name & \\
\hline Participant's name & \\
\hline Participant's position & \\
\hline Years in the company & \\
\hline Instructions to the interviewer & \\
\hline Research question & \\
\hline Other points to add to discussion & \\
\hline Reflective notes & \\
\hline $\begin{array}{l}\text { Other comments or Suggestions added by } \\
\text { informant }\end{array}$ & \\
\hline
\end{tabular}


- Conceptually ordered matrices for findings

Table 3. Conceptually ordered matrices for findings: Case study I and case study II cross-cases findings: leadership practices that fit into employees' cultural aspects-matrix

\section{Main category 1 based on culture: People value freedom and self-expression}

\begin{tabular}{|c|c|c|}
\hline & Case study I (pilot study) & Case study II \\
\hline \multicolumn{3}{|l|}{$\begin{array}{l}\text { Leadership } \\
\text { practice subcategories }\end{array}$} \\
\hline C1: macro management & $\begin{array}{l}\text { - Giving space to reach the agreed-on targets based on } \\
\text { rules and guidelines }\end{array}$ & $\begin{array}{ll}- & \text { Clarifying responsibilities and providing } \\
\text { clear guidelines }\end{array}$ \\
\hline $\begin{array}{l}\text { C2: involve employees } \\
\text { in decision making }\end{array}$ & $\begin{array}{ll} & \text { Involving subordinates in day-to-day decisions } \\
\text { - } & \text { Maintaining transparency in centralized decisions } \\
\end{array}$ & $\begin{array}{ll}\text { - } & \text { Involving employees in decisions making } \\
\text { - } & \text { Considering employees feedback } \\
\end{array}$ \\
\hline \multicolumn{3}{|c|}{ Main category 2 based on culture: People short-term orientation } \\
\hline & Case study I (pilot stud) & Case study II \\
\hline \multicolumn{3}{|l|}{$\begin{array}{l}\text { Leadership } \\
\text { practice subcategories }\end{array}$} \\
\hline $\begin{array}{l}\mathrm{C} 1 \text { : managing short- } \\
\text { term focus }\end{array}$ & $\begin{array}{ll} & \text { Clarifying the company vision } \\
\text { - } & \text { Clarifying long-term objectives } \\
\text { - } & \text { Linking short-term objectives to long-term ones }\end{array}$ & $\begin{array}{l}\text { - } \begin{array}{l}\text { Developing long-term plans to fulfil roles } \\
\text { and objectives }\end{array} \\
\text { - } \quad \begin{array}{l}\text { Helping employees realize the purpose of } \\
\text { the objectives }\end{array}\end{array}$ \\
\hline \multicolumn{3}{|c|}{ Main category 3 based on culture: People value working under clear context } \\
\hline & Case study I (pilot study) & Case study II \\
\hline \multicolumn{3}{|l|}{$\begin{array}{l}\text { Leadership practice } \\
\text { subcategories }\end{array}$} \\
\hline $\begin{array}{l}\mathrm{C} 1 \text { : providing and } \\
\text { communicating clear } \\
\text { rules and guidelines }\end{array}$ & $\begin{array}{l}\text { - Online consultancy service to guide employees } \\
\text { regarding any rules, regulations, regarding legal } \\
\text { issues, ethical issues, and employees' rights } \\
\text { Orientation sessions and complaisance courses to } \\
\text { update them with rules and regulations related to } \\
\text { their area of work }\end{array}$ & 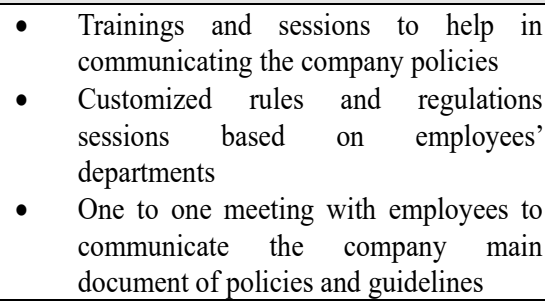 \\
\hline $\begin{array}{l}\text { C2: maintaining a follow } \\
\text { up system }\end{array}$ & $\begin{array}{l}\text { - } \quad \text { Clarifying business objectives } \\
\text { - } \quad \text { Coaching subordinate to develop and fulfil a yearly } \\
\text { plan to reach such objectives. } \\
\text { - } \quad \begin{array}{l}\text { Providing subordinate with training and recourses } \\
\text { needed }\end{array} \\
\text { - } \quad \text { Measuring subordinate progress for adjustments } \\
\end{array}$ & $\begin{array}{l}\text { - } \begin{array}{l}\text { Assessing employees' capabilities and } \\
\text { creating development plans for them, on }\end{array} \\
\text { yearly bases } \\
\text { - } \quad \text { Helping employees face challenges } \\
\text { - } \quad \text { Following up on employees' progress }\end{array}$ \\
\hline \multirow{2}{*}{$\begin{array}{l}\text { C3: maintaining a clear } \\
\text { rewarding and } \\
\text { penalizing system }\end{array}$} & $\begin{array}{ll}\text { - } & \text { Evaluation and appraisal rewards } \\
\text { - } & \text { Immediate acknowledgment for special efforts }\end{array}$ & $\begin{array}{llcl}- & \begin{array}{l}\text { Rewarding employees } \\
\text { development and progress }\end{array} & \text { based on } \\
\end{array}$ \\
\hline & $\begin{array}{l}\text { - Help employees learn from mistakes } \\
\text { - } \quad \text { Penalize repeated carelessness; using verbal } \\
\text { notification, written warring, and a corrective action. }\end{array}$ & $\begin{array}{ll}- & \text { Translating mistakes into lessons learned } \\
\text { - } & \text { Penalize violation of integrity and legal } \\
\text { policies }\end{array}$ \\
\hline \multicolumn{3}{|c|}{ Main category 4 based on culture: humane-orientation- People tendency to be emotional and subjective } \\
\hline & Case study I (pilot study) & Case study II \\
\hline \multicolumn{3}{|l|}{$\begin{array}{l}\text { Leadership } \\
\text { practice subcategories }\end{array}$} \\
\hline C1: managing conflicts & $\begin{array}{l}\text { - } \begin{array}{l}\text { Communicating to subordinate the companies' } \\
\text { policies }\end{array} \\
\text { - } \quad \text { Clarifying accountability } \\
\text { - Spending time to help employees get over their } \\
\text { personal issues and focus at work }\end{array}$ & $\begin{array}{l}\text { - } \quad \text { Helping subordinates deal with conflicts } \\
\text { - } \quad \text { Supporting employees to deal in an } \\
\text { objective rather than subjective way } \\
\text { Providing online training about dealing } \\
\text { with conflicts }\end{array}$ \\
\hline $\begin{array}{l}\text { C2: keep employees in } \\
\text { harmony }\end{array}$ & $\begin{array}{l}\text { - Nurturing good team spirit (lunch break, and team } \\
\text { building activities) } \\
\text { Holding compliance sessions to help employees } \\
\text { maintain healthy relationships and decrease conflict } \\
\text { of interest }\end{array}$ & $\begin{array}{l}\text { - } \text { Nurturing good team spirit } \\
\text { - Managing the conflict } \\
\text { - } \quad \begin{array}{l}\text { Providing a Web link to report } \\
\text { misconducts anonymously }\end{array}\end{array}$ \\
\hline $\begin{array}{l}\text { C3: considering } \\
\text { individuals' differences }\end{array}$ & $\begin{array}{ll}\text { - } & \text { Individual's level of experience } \\
\text { - } & \text { Personality and nature } \\
\text { - } & \text { Special social and religious norms }\end{array}$ & $\begin{array}{ll}\text { - } & \text { Individual's nature and personality } \\
\text { - } & \text { Personal circumstance } \\
\text { - } & \text { Special religions and social norms. }\end{array}$ \\
\hline
\end{tabular}

Source: researcher 


\section{References}

Burgess, J., \& Dyer, S. (2009). Workplace mentoring for indigenous Australians: a case study. Equal Opportunities International, 28(6),465-485. DOI: 10.1108/02610150910980774

Creswell, JW. (1994). Research design: qualitative, quantitative Approaches. (2nd ed.). Thousand Oaks, Calif.: Sage Publications.

Creswell, JW. (1998). Qualitative inquiry and research design: choosing among five traditions. (2nd ed.). Thousand Oaks: Sage Publications.

Debono, S., Jones, S., \& Van der Heijden, B. (Eds.). (2008). Managing cultural diversity. Oxford: Meyer \& Meyer Media (UK) Ltd.

Devers, K., \& Frankel, R. (2000). Study Design in qualitative research -2: sampling and data collection strategies. Education for Health: Change in Learning \& Practice, 13(2): 263-271. DOI: 10.1080/13576280050074543

Dickson, M. W., Den Hartog, D. N., \& Mitchelson, J. K. (2003). Research on leadership in a cross-cultural context: Making progress and raising new questions. The Leadership Quarterly, 14(6), 729-768. DOI: 10.1016/j.lequa.2003.09.002

Flynn, B. B., \& Saladin, B. (2006). Relevance of Baldrige constructs in an international context: A study of national culture. Journal of Operations Management, 24(5), 583-603. DOI: 10.1016/j.jom.2005.09.002

Goleman, D. (2000). Leadership that gets results. Harvard business review, 78(2), 78-90.

Grotenhuis, F. D. (2001). Marriages between Asian, American, and Dutch Corporations: a matter of cultural fit? Review of Pacific Basin Financial markets and Policies, 4(2), 203-220. DOI: 10.1142/S0219091501000383

Harris, S., \& Carr, C. (2008). National cultural values and the purpose of businesses. International Business Review, 17(1), 103-117. DOI: 10.1016/j.ibusrev.2007.08.002

HassabElnaby, H., \& Mosebach,M. (2005). Culture's consequences in controlling agency costs: Egyptian evidence. Journal of international accounting, auditing \& taxation, $14(1), 19 . \quad$ DOI: 10.1016/j.intaccaudtax.2005.01.003

Hofstede, G. (1994.a). Management scientists are human. Management Science, 40(1), 4-13.

Hofstede, G. (1994.b). Business cultures: every organization has its symbols, rituals and heroes. UNESCO Courier, 47(4), 12.

Hofstede, G. (1996). Riding the waves of commerce: a test of Trompenaars' "model" of national culture differences. International Journal Intercultural Relation, 20(2), 189-198. DOI: 10.1016/01471767(96)00003-X

Hofstede, G., Van Deusen, C., Mueller, C., Mueller, C., \& Charles, T. (2002). What goals do business leaders pursue? a study in fifteen countries. Journal of International Business Studies, 33(4), 785-803.

Huberman,M., \& Miles,M. (2002). The qualitative researcher's companion. Thousand Oaks: Sage Publication, Inc.

Ibrahim, A. (2014.a). A framework for developing leadership model based on national culture aspects, Journal of developing country studies, 4(22),109-117. https://doi.org/10.7176/DCS

Ibrahim, A. (2014.b). A shift in employees' perception towards leadership practice: an Egyptian Case study under cross-cultural settings. Journal of Developing Country Studies, 4(24),168-181. https://doi.org/10.7176/DCS

Ibrahim, A. (2014.c). Contextual factors that impact leadership practices in cross-cultural settings: an Egyptian case study. Journal of Developing Country Studies, 4(15), 155-168. https://doi.org/10.7176/DCS

Javidan, M., Dorfman, P., \& House, R. (2006). In the eye of the beholder: cross cultural lessons in leadership from project GLOBE. Academy of Management Perspectives, 20(1), 67-90. DOI: 10.5465/AMP.2006.19873410

Jepson, D. (2009). Leadership context: the importance of departments. Leadership \& Organization Development Journal, 30(1), 36-52. DOI: 10.1108/01437730910927098

Jones, G., \& George, J. (2003). Contemporary management. McGraw-Hill.

Karp Consulting Group, Inc. (2003). Improving Egyptian business' competitiveness: A survey of best practices. Report by USAID. July 16. Available: https://unctad.org/en/docs/iteteb20051_en.pdf

Kvale, S. (1996). Interviews: an introduction to qualitative research interviewing. Thousand Oaks: SagePublications

Leat, M., \& El-Kot, G. (2007). HRM practices in Egypt: the influence of national context? International Journal of Human Resource Management, 18(1), 147-158. DOI: 10.1080/09585190601068557

Maxwell, J. (2005). Qualitative research design: an interactive approach (2nd ed.). Thousand Oaks: Sage Publications.

McCracken, G. (1988). The long interview. Newbury Park, Calif: Sage Publications.

Morrison, A. (2000). Developing a global leadership model. Human Resource Management, 39(2), 117-131. DOI: 10.1002/1099-050X(200022/23)39:2/33.0.CO;2-1

Mostafa, M. (2005). Factors affecting organizational creativity and innovativeness in Egyptian business organizations: an empirical investigation. Journal of Management Development, 24(1), 7-33. DOI: $10.1108 / 02621710510572326$ 
Mostafa, M. M., \& El-Masry, A. (2008). Perceived barriers to organizational creativity a cross-cultural study of British and Egyptian future marketing managers. Cross Cultural Management: An International Journal, 14(1), 81-93. DOI: 10.1108/13527600810848845

Nafie, R. (2012). National Culture Transformation and Its Impact on Multinational Corporate Culture: Case study of Egypt. World Journal of Social Sciences, 2(1), 84-94. Available: http://wjsspapers.com/static/documents/January/2012/7.\%20Rania.pdf

Rivenbark L (2006). 5-D Leadership. HRM magazine, 51(1), 113-114.

Rubin \& Rubin (1995). Qualitative interviewing: the art of hearing data. Lodon: Sage Publications.

Scandura, T., \& Dorfman, P. (2004). Leadership research in an international and cross-cultural context. The Leadership Quarterly, 15(2): 277-307. DOI: 10.1016/j.leaqua.2004.02.004

Sidani Y (2006). Work values in the Arab culture. In: advances in Global Business Research proceedings of the 2006 Academy for Global Business Advancement Third World Congress, Kuala Lumpur, Malaysia,4-6 January 2006, pp. 608-615. available: https://www.academia.edu/255959/Work_Values_in_the_Arab_Culture

Silverman, D. (2000). Doing qualitative research: a practical handbook. Thousand Oaks: Calif.: SAGE.

Suutari, V. (1996. a). Leadership ideologies among European managers: a comparative survey in a multinational company. Scandinavian Journal of Management, 12(4), 389-409. DOI: 10.1016/S0956-5221(96)00017-6

Suutari, V. (1996. b). Variation in the average leadership behavior of managers across countries: Finnish expatriates' experiences from Germany, Sweden, France and Great Britain. The International Journal of Human Resource Management, 7 (3), 677-707. DOI: 10.1080/09585199600000150

Suutari, V., \& Riusala, K. (2001). Leadership styles in Central Eastern Europe: Experiences of Finnish expatriates in the Czech Republic, Hungary and Poland. Scandinavian Journal of Management, 17 (2), 249-280. DOI: 10.1016/S0956-5221(99)00037-8

Suutari,V., \& Tahvanainen, M. (2002). The antecedents of performance management among Finnish expatriates. The International Journal of Human Resource Management, 13(1), 55-75. DOI: 10.1080/09585190110092794

The Corporate Leadership Council. (2000). 3M's leadership competency framework. Catalog Number: CLC12NLK2, December. Corporate Executive Board. Available: https://www.scribd.com/document/53128781/3MsLeadershipCompetencyFramework

https://www.slideshare.net/rakshitaagrawal/3-msleadershipcompetencyframework

Trompenaars, F., \& Hampden-Turner. (1998). Riding the waves of culture: understanding diversity in global business. ( 2 ed.). New York: McGraw-Hill.

Van Oudenhoven, J. (2001). Do organizations reflect national cultures? A 10-nation study. International Journal of Intercultural Relations, 25(1), 89-107. DOI: 10.1016/S0147-1767(00)00044-4

Yin, R. (2003). Case study research: design and methods (3 ed.). Thousand Oaks, Calif: Sage Publications.

Yin, R. (2009). case study research design and methods (4 ed.). Sage Publications: Thousand Oaks, Calif.

\section{Acknowledgements}

I would like to express my gratitude to my supervisor Prof. Marc T. Jones for his great support and constructive feedback. 